\title{
Urea Excretion and Arginase Activity as New Biomarkers for Nitrite Stress in Freshwater Aquatic Animals
}

\author{
Gaetana Napolitano ${ }^{1, *(\mathbb{D})}$, Gianluca Fasciolo ${ }^{2}$, Claudio Agnisola ${ }^{2}$ and Paola Venditti ${ }^{2}$ \\ 1 Dipartimento di Scienze e Tecnologie, Università degli Studi di Napoli Parthenope, Via Acton n. 38, \\ I-80133 Napoli, Italy \\ 2 Dipartimento di Biologia, Università di Napoli Federico II, Complesso Universitario Monte Sant'Angelo, \\ Via Cinthia, I-80126 Napoli, Italy; gianluca.fasciolo@unina.it (G.F.); claudio.agnisola@unina.it (C.A.); \\ paola.venditti@unina.it (P.V.) \\ * Correspondence: gaetana.napolitano@uniparthenope.it
}

Citation: Napolitano, G.; Fasciolo, G.; Agnisola, C.; Venditti, P. Urea Excretion and Arginase Activity as New Biomarkers for Nitrite Stress in Freshwater Aquatic Animals. Water 2021, 13, 3521. https://doi.org/ $10.3390 / w 13243521$

Academic Editors: Laura Guimarães and Carlos Gravato

Received: 28 October 2021

Accepted: 6 December 2021

Published: 9 December 2021

Publisher's Note: MDPI stays neutral with regard to jurisdictional claims in published maps and institutional affiliations.

Copyright: (c) 2021 by the authors. Licensee MDPI, Basel, Switzerland. This article is an open access article distributed under the terms and conditions of the Creative Commons Attribution (CC BY) license (https:// creativecommons.org/licenses/by/ $4.0 /)$.

\begin{abstract}
Background: In recent years, the concern has been growing on increasing aquatic nitrite levels due to anthropogenic activities. Crustaceans and fish easily uptake nitrite via the chloride uptake system of gills. High nitrite body levels may interfere with nitric oxide (NO) production by nitric oxide synthase (NOS). The arginase, which catalyzes arginine conversion to ornithine and urea, is central to NO homeostasis. In vivo, changes in the arginase activity alter urea body levels and urea excretion and modulate NOS by altering arginine availability for NO synthesis. Excess arginase activity may uncouple NOS and induce oxidative stress. Methods: We tested muscle arginase activity and urea excretion in two fish species, zebrafish and convict cichlid, and the crustacean Yamato shrimp, under sub-lethal nitrite stress. Results: Exposure to nitrite ( $2 \mathrm{mM}$ in the fish, $1 \mathrm{mM}$ in the shrimp) significantly increased blood nitrite concentration in all species. Concomitantly, nitrite stress significantly increased arginase activity, urea excretion, and urea levels in the blood. In Yamato shrimp, urea levels also increased in muscle. Conclusion: Our results agree with the hypothesis that nitrite stress affects NO homeostasis by arginase stimulation and urea excretion. These parameters might function as markers of sub-lethal nitrite stress in freshwater fish and crustaceans.
\end{abstract}

Keywords: nitrite; arginase; nitric oxide; nitric oxide synthase; urea excretion; Danio rerio; Amatitlania nigrofasciata; Caridina multidentata

\section{Introduction}

In recent years, the harmful effects of nitrite $\left(\mathrm{NO}_{2}{ }^{-}\right)$on aquatic organisms have attracted much attention due to the rapid growth of urban and industrial areas that cause an increased influx of nitrogenous compounds into aquatic ecosystems. Nitrite is an intermediate of the nitrogen cycle, a primary regulator of the functional organization and integrity of ecosystems, which can be affected by numerous factors, including $\mathrm{pH}$, temperature, and oxygen availability, as well as a diversity of inorganic and organic compounds [1]. The nitrite levels in aquatic environments are usually low. They depend on the balance between nitrification (reduction of ammonia to nitrite and nitrate) and denitrification (nitrate/nitrite conversion to $\mathrm{N}_{2}$ ). The global increase in availability and mobility of nitrogenous compounds by human activity can favor nitrification over denitrification and as such it can increase nitrite concentrations in aquatic environments even into the $\mathrm{mM}$ range [1]. High nitrite levels may also occur in closed intensive culture systems due to excessive ammonia release and insufficient, inefficient, or malfunctioning water filtration [2]. Elevated nitrite levels in the environment have toxic effects on living organisms [1,3]. Freshwater crustaceans and fish can uptake and even accumulate nitrite with several detrimental consequences. The problem of freshwater animals with nitrite pollution derives from the high affinity of nitrite for the chloride uptake system [4,5]. When nitrite is present in the ambient water, a part of the $\mathrm{Cl}^{-}$uptake will be shifted to $\mathrm{NO}_{2}^{-}$uptake [4]. Consequently, 
most freshwater fish and crustaceans actively uptake this ion in their plasma and, to a lesser extent, in various organs and tissues, including gills, liver, brain, and muscles [6,7].

Nitrite is usually present in the animal body as an essential component of the nitric oxide homeostatic system [8]. It is produced mainly as an oxidative metabolite of nitric oxide (NO) and can function as an NO reservoir. For example, under hypoxia, when the shortage of $\mathrm{O}_{2}$ compromises NOS activity, nitrite can be recycled to NO by many proteins (e.g., deoxyhemoglobin, deoxymyoglobin, and xanthine reductase, etc. [8]). Physiological extracellular levels of nitrite in fish and crustaceans are in the micromolar range [4]. Higher nitrite levels in the body can affect body metabolism, including methemoglobin or metahemocyanin formation and metabolic hypoxia, reduction in plasmatic chloride, and excess NO production [1,9]. Alterations of NO metabolism have relevant consequences with inhibition of enzyme activities, endocrine disruption, nitrosative stress, and oxidative stress. NO compromises $\mathrm{Na}^{+} / \mathrm{K}^{+}$ATPase activity in gills and kidneys of salmonids, thus reducing the osmoregulation capacity of animals [10]. Moreover, the excess NO production is likely involved in nitrite-dependent alterations in embryo development and reduced fecundity in Daphnia magna [9]. NO also influences mitochondrial cytochrome oxidase activity, compromising cellular adaptations to environmental oxygen concentrations [11]. A delicate homeostatic balance tightly regulates NO levels. This process involves nitric oxide synthase (NOS) and arginase activities. NOS catalyzes the incorporation of molecular oxygen and the release of $\mathrm{NO}$ from the guanidino nitrogen terminal group of arginine. The reaction produces citrulline as a by-product [12]. The arginase is a metalloenzyme containing manganese in the active site and catalyzes the conversion of arginine to ornithine and urea. Therefore, it determines urea production and excretion in ammoniotelic organisms [13]. Arginase activity is highly regulated, and changes in its activity can significantly impact many critical physiological and pathophysiological processes [14]. In particular, arginase can effectively compete with NOS for the substrate arginine and may function as a modulator of arginine-NO homeostasis $[13,15]$. However, when arginase activity is excessive, the supply of arginine required for NO production is insufficient, thus resulting in oxidative stress. In fact, with a low arginine supply NOS will uncouple, producing lesser $\mathrm{NO}$ and generating superoxide from molecular oxygen [16]. The superoxide will react rapidly with any available $\mathrm{NO}$ to form peroxynitrite, further decreasing $\mathrm{NO}$ and further uncoupling NOS by oxidizing the cofactor $\mathrm{BH}_{4}$ [17].

Several pieces of evidence show that nitrite accumulation may cause excessive production of NO, so disturbing NO homeostasis, and it contributes to nitrite toxicity $[4,9,18]$. Little is known on the putative involvement of arginase involvement in the response to the environmental nitrite stress in aquatic animals. To test this hypothesis, we compared the effects of acute nitrite exposition in three experimental models, the two freshwater fish zebrafish (Danio rerio, Hamilton 1822) and convict ciclid (Amatitlania nigrofasciata, Gunther, 1866), and the crustacean Yamato shrimp (Caridina multidentata, Stimpson, 1860). The choice of these species relies on their different susceptibility to nitrite exposure. Fishes are more resistant with respect to crustacean models, even though differences within classes of freshwater animals exist [1]. We evaluated nitrite accumulation in blood/hemolymph, arginase activity, and urea levels in the blood and muscular tissues, as well as urea excretion rate. Muscle tissue was selected as the most massive component of the body so that any change in the arginase activity will have a significant impact on the whole-body arginine homeostasis. The results suggest that the stimulation of arginase and urea excretion is a common response to nitrite stress in both fish and crustaceans.

\section{Materials and Methods}

\subsection{Animals}

The freshwater fish species chosen for the experiments were the zebrafish and convict ciclid. Yamato shrimps were used to compare fish responses with the reactions of crustaceans. 
Local supply store (CARMAR, Italy) furnished juveniles specimens of both sexes of zebrafish (body length, $\mathrm{BL},<1.5 \mathrm{~cm}$, average weight $\sim 0.5 \mathrm{~g}$ ), convict cichlid ( $\mathrm{BL}<10 \mathrm{~cm}$, average weight $\sim 10 \mathrm{~g}$ ), and Yamato shrimp ( $\mathrm{BL}<1.5 \mathrm{~cm}$, average weight $\sim 0.4 \mathrm{~g}$ ).

Fish were acclimated in indoor $200 \mathrm{~L}, 27^{\circ} \mathrm{C}$ glass aquaria with dechlorinated, continuously filtered, and aerated freshwater, for a minimum of 40 days with a $10 \mathrm{~h}: 14 \mathrm{~h}$ light-dark photoperiod before being used for experiments.

Zebrafish were maintained in low conductivity water $(<1000 \mu \mathrm{s})$ in schools of at least 50 individuals. Convict cichlid, a territorial species, was kept in tap water at a low density ( $\leq 10$ individuals per thank). Tanks were enriched with rocks and other structures to provide shelter and hiding places for the animals [19]. Yamato shrimps were placed in $35 \mathrm{~L}$ maintenance tanks equipped with Grey Quartz Gravel (Blue Line) and filled with dechlorinated, continuously filtered, aerated freshwater whose conductivity was $\leq 350 \mu$ s. Pots and plastic plants were added to create refuges. The water temperature was $27^{\circ} \mathrm{C}$. During acclimation, temperature, $\mathrm{pH}(6<\mathrm{Ph}<7)$, conductivity, and levels of ammonia, nitrite, and nitrate were checked once a week.

Fish were fed daily with commercial pelleted fish food (Tetramin, Tetra, Germany; $47 \%$ crude protein content, $6 \%$ humidity, $20.1 \mathrm{~kJ} / \mathrm{g}$ dry weight). Twice a week, Tetramin was replaced with Chironomus larvae (Eschematteo s.r.l., Parma, Italy, 7.01\% crude protein content, $89 \%$ humidity, $21.9 \mathrm{~kJ} / \mathrm{g}$ dry weight). Yamato shrimps were fed daily with micro pellets (SERA).

Acclimated animals were divided into experimental groups, control and treated, according to the experimental protocols described below. The animals were selected randomly and isolated into appropriate net cages set in the same tank used for acclimation and were fasted for $48 \mathrm{~h}$ before use [20]. Animal procedures on fish were approved by the Institutional Animal Care and Use Committee (CESA) of the University of Naples Federico II, Naples, Italy (Approval number 47339-2013).

\subsection{Nitrite Stress Procedure}

After the acclimatization period, treated animals were exposed to submaximal concentrations of sodium nitrite $\left(\mathrm{NaNO}_{2}\right.$, Merck KGaA, Darmstadt, Germany) dissolved in water containing less than $100 \mathrm{mM}$ chloride ( $\mathrm{N}=6$ for each species). Simultaneously, control groups ( $\mathrm{N}=6$ for each species) were exposed to the same water but without adding sodium nitrite. Convict cichlid and Yamato shrimp were exposed to $\mathrm{NaNO}_{2}$ for $3 \mathrm{~h}$ ( $2 \mathrm{mM}$ and $1 \mathrm{mM}$ final concentrations, respectively for convict cichlid and Yamato shrimp), while zebrafish was exposed for $24 \mathrm{~h}$ (2 $\mathrm{mM}$ final concentration) [18,21]. Preliminary tests on concentration and time-dependent mortality allow setting nitrite concentrations and exposure time. We chose the minimal concentrations and exposure time not inducing mortality. During exposure, water samples were collected at intervals to determine the average urea excretion. At the end of the treatment, blood/hemolymph samples were collected to measure nitrite accumulation. Fish were euthanized with benzocaine $\left(0.05-0.1 \mathrm{mg} \mathrm{mL}^{-1}\right)$. Muscle tissue from all animals was dissected, weighed, quickly frozen in liquid nitrogen, and stored at $-80^{\circ} \mathrm{C}$. Frozen tissues were successively used for the preparation of homogenates. Samples from all animals in each treatment trial were pooled. Treatments were replicated five times on each species.

\subsection{Blood/Hemolymph Sample Collection and Evaluation of Nitrite Accumulation}

Blood samples and hemolymph were treated according to Dalla Via [22]. Nitrite $\left(\mathrm{N}-\mathrm{NO}_{2}\right)$ determination was performed using the Griess reagent spectrophotometric method [23]. In brief, $50 \mu \mathrm{L}$ of heparinized blood or hemolymph was added to $0.3 \mathrm{~mL}$ of $4.31 \% \mathrm{ZnSO}_{4}$ (Sigma-Aldrich, Munich, Germany). After mixing, $0.2 \mathrm{~mL}$ of distilled water and $50 \mu \mathrm{L}$ of $4 \% \mathrm{NaOH}$ were added. The suspension was kept at $0{ }^{\circ} \mathrm{C}$ for $1 \mathrm{~h}$ and centrifuged at $15,000 \times g$ for $15 \mathrm{~min}$ to eliminate the protein component $[6,24]$. The resulting supernatants, diluted to a final volume of $1 \mathrm{~mL}$, were added with $0.1 \mathrm{~mL}$ of Griess reagent (Sigma-Aldrich, Munich, Germany), kept to dark for $15 \mathrm{~min}$, and read at $520 \mathrm{~nm}$ in a 
DR/2400 Hach spectrophotometer (Hach, Loveland, CO, USA). Nitrite concentrations of samples were obtained using a calibration curve of $\mathrm{N}^{-\mathrm{NO}_{2}}$.

\subsection{Preparation of Tissue Homogenates}

Muscle homogenates preparations are dependent on the parameter determined.

For the determination of urea levels, samples were treated according to Dunn [25]. In brief, the muscle tissue was gently homogenized ( $20 \%$ weight: volume) in $7 \%$ perchloric acid using a glass Potter-Heidolph homogenizer (Schwabach, Germany) set at a standard velocity (500 rpm) for $1 \mathrm{~min}$. Tissue homogenates were centrifuged at 20,000 $\times \mathrm{g}$ for $15 \mathrm{~min}$ at $4{ }^{\circ} \mathrm{C}$. The resulting supernatants were neutralized at $\mathrm{pH} 7.5$ with a solution containing $3 \mathrm{M} \mathrm{K}_{2} \mathrm{CO}_{3}$ and $0.1 \mathrm{M}$ triethanolamine. The samples were re-centrifuged at $20,000 \times g$ for $15 \mathrm{~min}$ at $4{ }^{\circ} \mathrm{C}$. The resulting supernatants were used for the determination of protein concentration by the Biuret method [26] and subsequent analysis.

For the determination of arginase activity, muscle tissue samples were gently homogenized ( $20 \%$ weight: volume) in a homogenization buffer $(0.05 \mathrm{M} \mathrm{KCl}, 0.05 \mathrm{M}$ Hepes, $0.5 \mathrm{mM}$ EDTA, $1 \mathrm{mM}$ DTT, pH 7.5) [27] using a glass Potter-Heidolph homogenizer set at a standard velocity (500 rpm) for $1 \mathrm{~min}$. The homogenate was sonicated with a Sonic Vibra Cell sonicator (Newtown, CT, USA) for one minute and centrifuged at $15,000 \times g$ for $20 \mathrm{~min}$ at $4{ }^{\circ} \mathrm{C}$ [28]. The resulting supernatants, that contain the soluble fraction plus the content of the mitochondrial matrix, were used for the determination of protein concentration (by the Biuret method) [26] and subsequent analysis.

\subsection{Determination of Urea Excretion and Tissue Urea Levels}

Urea levels in water samples, blood and muscle homogenates were colorimetrically measured using the diacetyl-monoxime method (modified from Rahmatullah and Boyde [29]). Briefly, $1 \mathrm{~mL}$ samples were added to $0.5 \mathrm{~mL}$ of urea reactant $\left(8.3 \mathrm{mg} \mathrm{mL}^{-1}\right.$ 2,3-Butanedion monoxime, $0.2 \mathrm{mg} \mathrm{mL}^{-1}$ Thiosemicarbazide, and $0.1 \mathrm{mg} \mathrm{mL}^{-1} \mathrm{FeCl}_{3}$ in $\left.32 \% \mathrm{H}_{2} \mathrm{SO}_{4}\right)$, and the mixture reaction was heated in dark $\left(100{ }^{\circ} \mathrm{C}, 10 \mathrm{~min}\right)$. After cooling (in dark, for $12 \mathrm{~min}$ ), urea levels were determined spectrophotometrically at $535 \mathrm{~nm}$ in a DR/2400 Hach spectrophotometer (Hach, Loveland, CO, USA). Time variation of urea levels in the exposure water allowed to determine urea excretion $\left(\mathrm{M}_{\text {urea }}\right)$, expressed as mmol- $\mathrm{N} \mathrm{h}^{-1} \mathrm{~kg}^{-1}$. Thiosemicarbazide and 2,3-Butanedion monoxime were from SigmaAldrich (Munich, Germany).

\subsection{Determination of Muscle Arginase Activity}

Muscle arginase activity was assayed in terms of the rate of urea formation according to Romero [16]. In brief, $1 \mathrm{~mL}$ of muscle were incubated for $1 \mathrm{~h}$ with $\mathrm{MnSO}_{4}(100 \mathrm{mM}$, $\mathrm{pH} 7.0$ at $\left.27^{\circ} \mathrm{C}\right)$ to activate the enzyme. Successively, L -Arginine $(0.4 \mathrm{~mL}, 713 \mathrm{mM}, \mathrm{pH} 9.5)$ was added and incubated for $30 \mathrm{~min}$ at $27^{\circ} \mathrm{C}$. Urea levels were measured as described above, and the arginase activity was expressed as $\mu \mathrm{m}$ of urea $\mathrm{h}^{-1} \mathrm{~g}^{-1}$. Arginine was from Sigma-Aldrich (Munich, Germany).

\subsection{Statistical Analysis}

All data are presented as means \pm standard error (S.E.). Differences in control values among the three species were tested by one-way ANOVA, with Bonferroni or Dunnett post hoc test $(p<0.05)$. The comparison between treated and control animals was tested within each species by Student- $t$ test $(p<0.05)$.

\section{Results}

In all species, the treatment with sub-lethal environmental levels of nitrite $\left(\left[\mathrm{NO}_{2}{ }^{-}\right]_{\mathrm{e}}=1 \mathrm{mM}\right.$ in the crustacean Yamato shrimp and $2 \mathrm{mM}$ in the two fish species, convict cichlid, and zebrafish) significantly increased the nitrite concentration in the inner fluids (Figure 1). Only in Yamato shrimp did a significant accumulation occur $\left(\left[\mathrm{NO}_{2}{ }^{-}\right]_{\mathrm{i}} /\left[\mathrm{NO}_{2}{ }^{-}\right]_{\mathrm{e}}=4.1\right)$. In both fish species, the blood nitrite concentration remained in the $\mu \mathrm{M}$ range. However, in 
zebrafish, blood nitrite concentration reached levels 10 times higher than in convict cichlid. Interestingly, the control nitrite concentration was significantly higher in zebrafish than in convict cichlid (Figure 1).
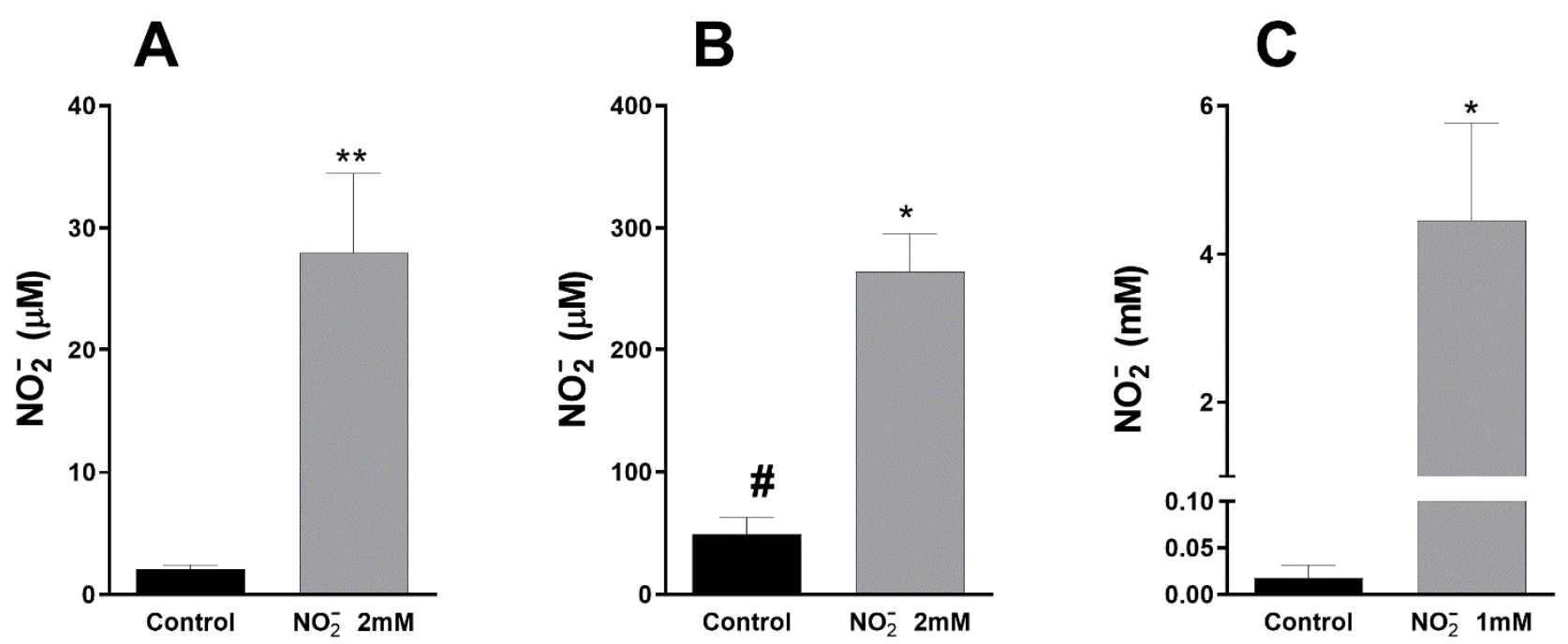

Figure 1. Nitrite levels in convict cichlid (A) and zebrafish (B) blood, and in Yamato shrimp hemolymph (C) following nitrite stress (convict cichlid and zebrafish: $2 \mathrm{mM}$ for $3 \mathrm{~h}$ and $24 \mathrm{~h}$, respectively; Yamato shrimp: $1 \mathrm{mM}$ for $3 \mathrm{~h}$ ). Data are means \pm SE of 5 determinations. In all three species there was a significant increase in the inner fluid nitrate levels ( $t$-student, $\left.{ }^{*} p<0.05 ;{ }^{* *} p<0.01\right)$. One-way ANOVA demonstrated that control nitrite levels was significantly higher in zebrafish (\#) than in both convict cichlid (adjusted $p=0.015$ ) and Yamato shrimp (adjusted $p=0.011$ ).

Parallel to the increase in body fluid nitrite concentration, a significant increase in the activity of muscular arginase occurred (Figure 2). This increase was relatively small in Yamato shrimp (treated / control ratio $=1.22)$ and convict cichlid (treated $/$ control ratio $=1.83$ ) but was very high in zebrafish (treated/control ratio $=12.0$ ).
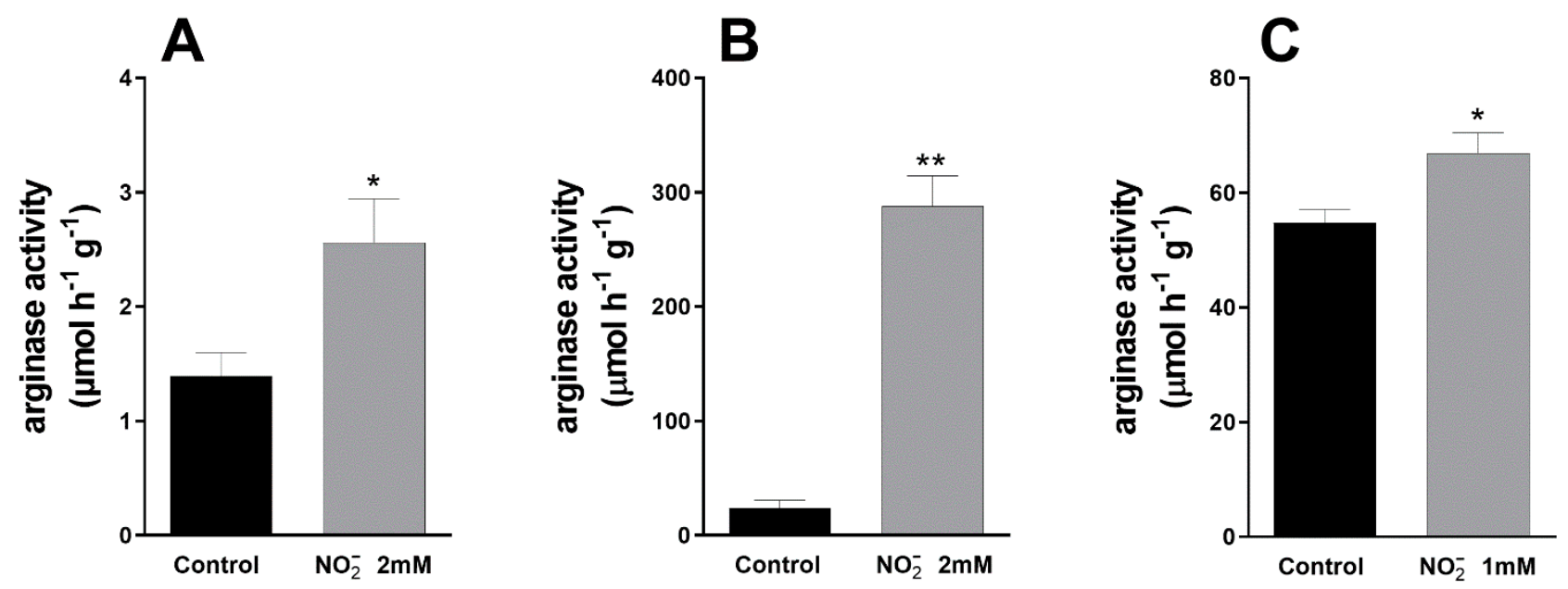

Figure 2. Stimulation of arginase activity in muscle homogenates from convict cichlid (A) and zebrafish (B) blood, and in Yamato shrimp hemolymph (C) by nitrite stress (convict cichlid and zebrafish: $2 \mathrm{mM}$ for $3 \mathrm{~h}$ and $24 \mathrm{~h}$, respectively; Yamato shrimp: $1 \mathrm{mM}$ for $3 \mathrm{~h}$ ). Data are means \pm SE of 5 determinations. In all three species, there was a significant increase in the urea excretion rate ( $t$-student, ${ }^{*} p<0.05 ;{ }^{* *} p<0.01$ ). One-way ANOVA, followed by Tukey's multiple comparison test, demonstrated that control arginase activity was significantly different among the three species, with Yamato shrimp showing the highest value and convict cichlid the lowest $(p<0.001)$.

Considering that the muscle tissue is a relatively high percentage of body mass, the stimulation of arginase activity could significantly increase whole body urea production 
in vivo in all three species. In effect, a significant increase in urea excretion was observed (Figure 3), higher in Yamato shrimp (about 21 times than the control) than in the two fish species (about 5 fold increase, and 5.5 fold increase, in convict cichlid and zebrafish, respectively).
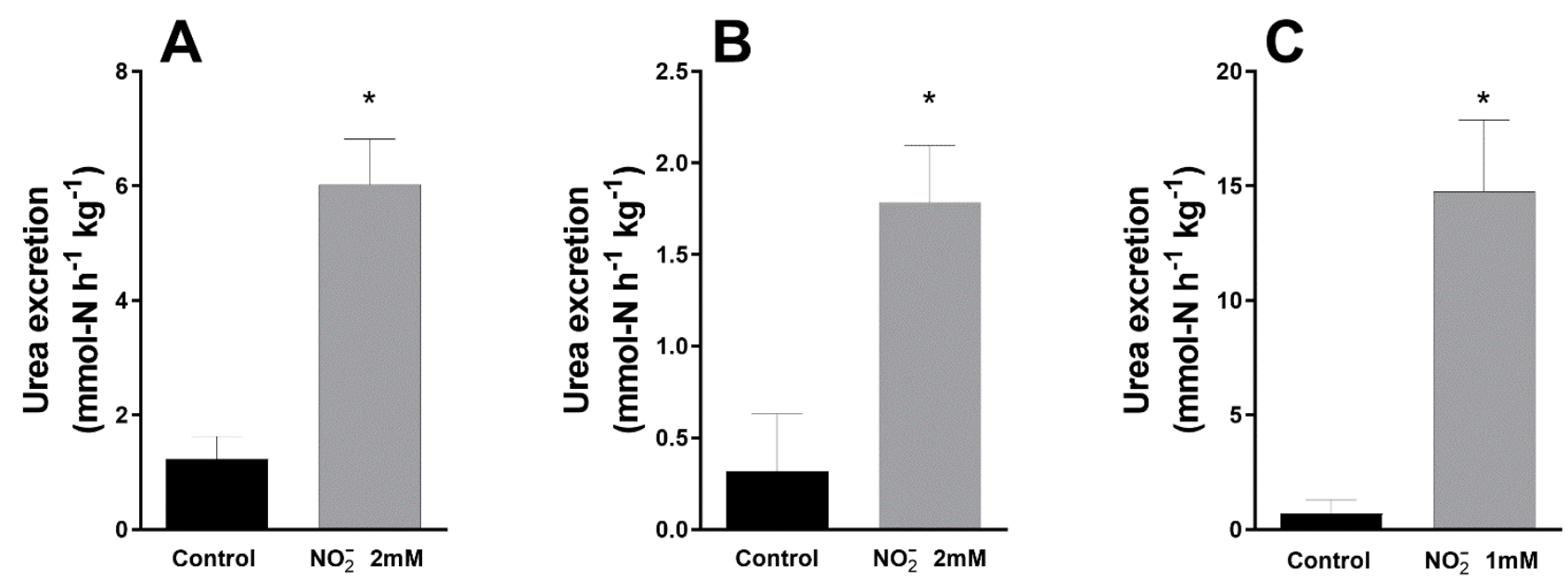

Figure 3. Stimulation of urea excretion in convict cichlid (A) and zebrafish (B) blood, and in Yamato shrimp hemolymph (C) induced by nitrite stress (convict cichlid and zebrafish: $2 \mathrm{mM}$ for $3 \mathrm{~h}$ and $24 \mathrm{~h}$, respectively; Yamato shrimp: $1 \mathrm{mM}$ for $3 \mathrm{~h}$ ). Data are means \pm SE of 5 determinations. In all three species, there was a significant increase in the urea excretion rate ( $t$-student, $\left.{ }^{*} p<0.05\right)$. There was no significant difference in the control excretion of urea among the three species (One-way ANOVA).

In Yamato shrimp, this increase in urea production was associated with higher urea levels in muscle (Figure 4), while blood urea levels were significantly increased in all three species (Figure 5).
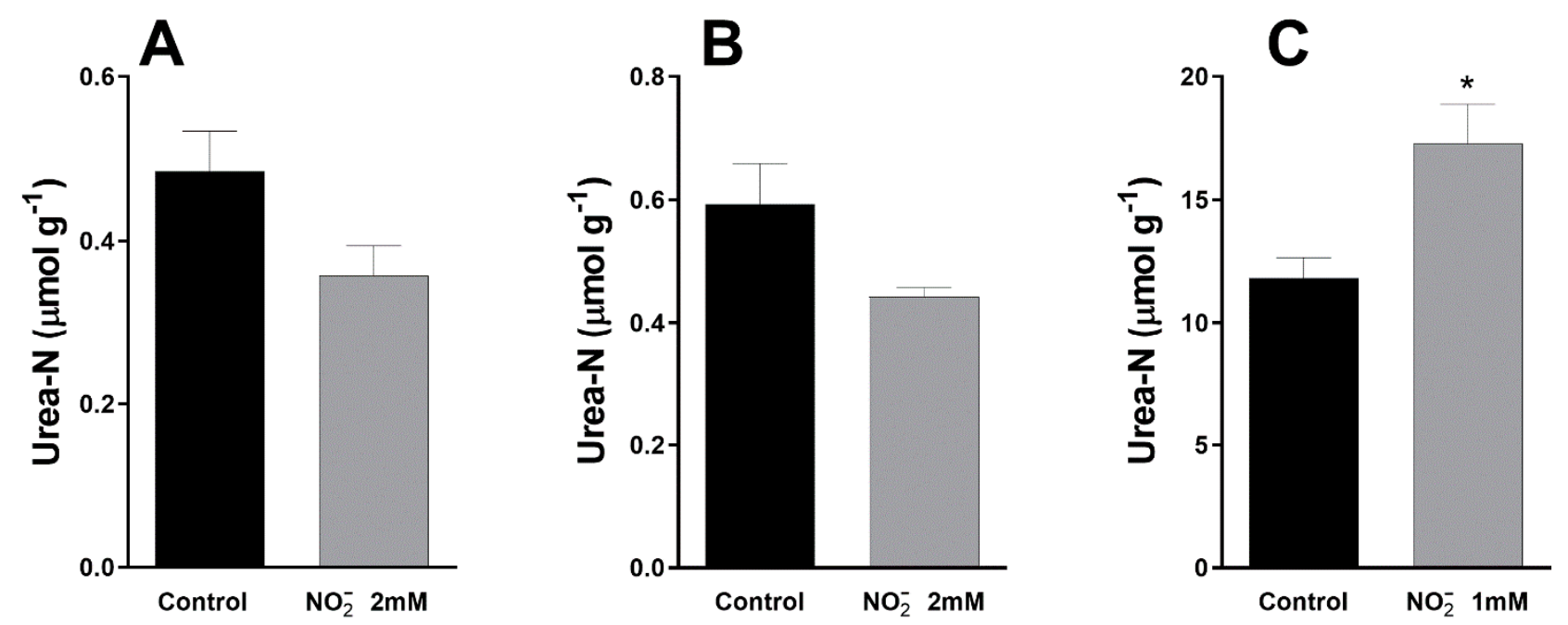

Figure 4. Stimulation of muscle levels of urea in convict cichlid (A) and zebrafish (B) blood, and in Yamato shrimp hemolymph (C) induced by nitrite stress (convict cichlid and zebrafish: $2 \mathrm{mM}$ for $3 \mathrm{~h}$ and $24 \mathrm{~h}$, respectively; Yamato shrimp: $1 \mathrm{mM}$ for $3 \mathrm{~h}$ ). Data are means $\pm \mathrm{SE}$ of 5 determinations. In Yamato shrimp, there was a significant increase in the urea content of muscle ( $t$-student, $p<0.01)$. One-way ANOVA, followed by Tukey's multiple comparison test, demonstrated that the control urea content of Yamato shrimp muscle was much higher than in both fish species (adjusted $p$-value $<0.0001$ ). 

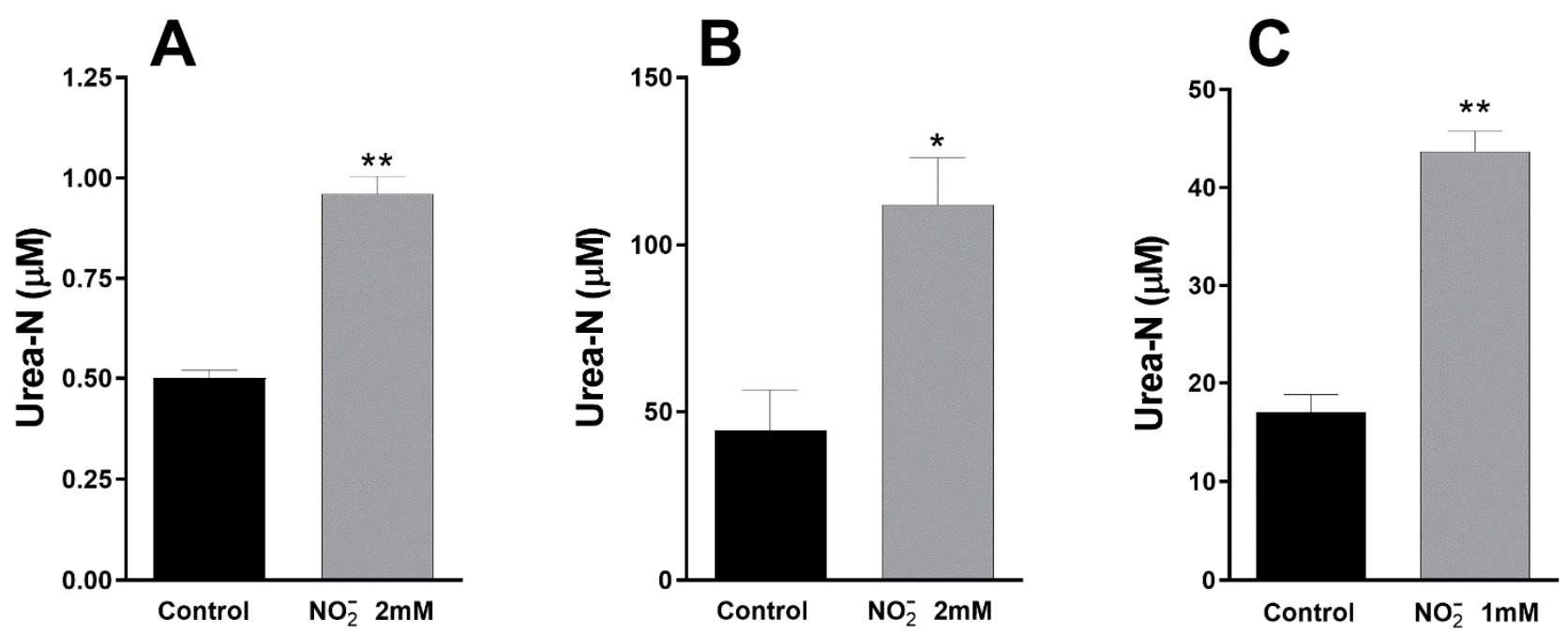

Figure 5. Stimulation blood/hemolymph levels of urea in convict cichlid (A) and zebrafish (B) blood, and in Yamato shrimp hemolymph (C) induced by nitrite stress (convict cichlid and zebrafish: $2 \mathrm{mM}$ for $3 \mathrm{~h}$ and $24 \mathrm{~h}$, respectively; Yamato shrimp: $1 \mathrm{mM}$ for $3 \mathrm{~h}$ ). Data are means \pm SE of 5 determinations. There was a significant increase in blood urea levels in all the three species ( $t$-student, $\left.{ }^{*} p<0.05 ;{ }^{* *} p<0.01\right)$. One-way ANOVA, followed by Tukey's multiple comparison test, demonstrated that control urea content of zebrafish blood was significantly higher than in convict cichlid (adjusted $p$-value $=0.0022$ ) and Yamato shrimp (adjusted $p$-value $=0.0240$ ).

\section{Discussion}

The results reported in our study show that nitrite exposure stimulates arginase activity and urea excretion with specie-specific effects (see synopsis in Table 1). Under exposition to nitrites, most freshwater fish and crustaceans actively accumulate this ion within their plasma [3,4]. Accordingly, the three model species increased their blood or hemolymph nitrite levels. However, different rates of uptake were observed. Only Yamato shrimp accumulates nitrite in the hemolymph. In zebrafish and convict cichlid blood, nitrite increases to levels that remain much lower than the exposure value $(2 \mathrm{mM})$. As high circulating nitrite levels are believed to be the primary source of nitrite stress in aquatic animals [2], these differences may reflect different sensitivity to nitrite stress among species [1]. Nitrite concentrations within the hemolymph of freshwater crustaceans often far exceed the concentration of the external medium so explaining higher nitrite toxicities [3]. For example, the European crayfish (Astacus astacus, Linnaeus) displayed hemolymph nitrite levels up to four times higher than trout when exposed to the same nitrite concentrations under the same environmental conditions [30,31]. The reason for this nitrite accumulation in crustacean hemolymph remains unknown yet. In comparison with fish, freshwater crayfish and shrimps were supposed to manifest a higher rate of chloride uptake and/or a higher affinity to nitrite of the gills ion exchange system [32].

Table 1. Summary of the main results of the present study, highlighting the stimulatory effect of nitrite sublethal stress on the arginase activity and urea excretion in the freshwater animals tested. $0=$ no effect; $+=$ increase $/$ stimulation; $++=$ strong increase $/$ stimulation.

\begin{tabular}{cccc}
\hline & Convict Cichlid & Zebrafish & Yamato Shrimp \\
\hline Blood/hemolymph nitrite level & + & + & ++ \\
Urea excretion & + & + & ++ \\
Muscle arginase activity & + & ++ & + \\
Muscle urea levels & 0 & 0 & + \\
Blood/hemolymph urea level & + & + & + \\
\hline
\end{tabular}

The increased nitrite levels in blood or hemolymph are associated with a significant urea excretion for all three animal models. This effect is very high in the shrimp Yamato 
shrimp. Urea production may derive from the ornithine-urea cycle (OUC), hydrolysis of arginine (argininolysis), and degradation of uric acid in the uricolytic pathway [33]. Decapod crustaceans excrete nitrogen mainly as ammonia (accounting for $60-70 \%$ of the total excreted nitrogen), with small amounts of urea and uric acid [34]. Lee and Chen [35] showed an eight-fold increase in urea-N excretion, following $24 \mathrm{~h}$ exposure to nitrite at $1.39 \mathrm{mM}$ in the prawn $M$. japonicus. They concluded that the animals spent energy to produce urea as organic nitrogenous waste to reduce joint toxicities of ammonia and incorporated nitrite. We can hypothesize that the significant nitrite accumulation in Yamato shrimp hemolymph stimulates urea-N excretion as an adaptative mechanism to preserve the crustacean's well-being. Fishes, being aquatic animals, release ammonia as the product of nitrogen excretion, and it is supposed that the urea cycle for urea production is suppressed in all freshwater fishes [36]. However, being OUC function lost in adult ammoniotelic fishes and the capacity to produce urea low, the retainment of urea transporters suggests that these proteins may be helpful under given circumstances [37]. Different authors reported an association between the increased cortisol levels and the activation of gluconeogenesis and proteolysis under stress conditions in teleost fish $[37,38]$. These biochemical pathways result in elevated plasma ammonia levels $[37,38]$ and the stimulation of urea synthesis as a detoxification pathway [39].

Higher production of urea under stress conditions may imply stimulation of arginolysis, as suggested by our experiments that show an increased muscle arginase activity in all three tested species. Arginase is a manganese metalloenzyme that catalyzes the conversion of L-arginine to L-ornithine, the precursor for polyamines and prolines, and urea [13]. Our results on Yamato shrimp are in part supported by Lee and Chen [35]. They showed that M. japonicus individuals exposed to elevated environmental nitrite increased nitrogen excretions, including urea excretion, and arginase activity and concluded that nitrite stimulated arginolysis [35]. Recently it has been reported that nitrite induces changes in the hepatopancreas gene expression of a high number of metabolic pathways, including those related to arginine and proline metabolism [40]. These results support the putative involvement of arginase in the crustacean's nitrite stress response. It is of note that, despite the greater excretion of urea in Yamato shrimp than in both fish species, the increase in muscle arginase activity in the crustacean model was relatively small. It is possible that the arginase localized in other tissue may significantly contribute to urea production in Yamato shrimp. In fact, in the freshwater shrimp Astacus Leptodactylus, the arginase activity is greater in gills and ovaries than in muscle and hepatopancreas [41]. Interestingly, the increased muscle arginase activity is not associated with urea retention in convict cichlid and zebrafish. Compared to the fish models, in Yamato shrimp, the arginase activity in the muscle is accompanied by an increase in the tissue levels of urea. This observation may be linked to differences in the urea transport capacity of muscle cells between crustaceans and fish. There are three fundamental ways by which urea crosses membranes: through specialized membrane transporters, lipid phase permeation, or paracellular channels. The traditional view of urea transport is that urea crosses all cell membranes by lipid phase permeation. However, the permeability of lipid bilayers to urea is low, so active or facilitated urea transports are present in several tissues [42]. Specific urea transporters can locate in the muscle tissues of convict cichlid and zebrafish to translocate urea in blood and facilitate its excretion. This hypothesis could also explain the increase in blood urea levels in both species of fish. However, available data do not allow us to give an exhaustive explanation for the difference in urea muscle retention between fish and crustaceans, as little information is available for muscle urea transporters in crustaceans. Nitrite stress has been reported to induce oxidative stress both in fish [43] and crustaceans [44]. Moreover, it can affect heart development by altering the NO signaling pathway in zebrafish [45]. Oxidative stress, a condition in which free radical and reactive oxygen species (ROS) generation exceed the cell antioxidant capacity [46], has been associated with the arginase activity increase [47]. Wang and co-workers showed that an imbalance between prooxidant forces and antioxidant defenses is one of the toxicity mechanisms of nitrite on prawn 
P. vannamei [48]. It is also reported that in Megalobrama amblycephala $72 \mathrm{~h}$ of nitrite exposure was associated with increased ROS generation and reduced antioxidant enzymes activity catalase, glutathione peroxidase, and superoxide dismutase [49]. Moreover, the increased tissue levels of urea deriving from increased arginase activity could affect the redox state since it may play a role in the stress response as an antioxidant molecule [50,51].

\section{Conclusions and Perspectives}

Exposure to elevated nitrite environmental concentration affects the arginase pathway and urea metabolism in a species-specific way according to a different susceptibility.

Despite the species-specificity differences in the response, the stimulation of arginase activity and urea excretion rate appears to be common responses that can be proposed as biomarkers of nitrite stress. However, further study is required to understand the mechanisms, limits, and long-term consequences of this response. In future experiments, we aim to analyze the redox state unbalance associated with nitrite exposure and its interference into homeostatic processes regulated by the enzyme, as it appears to be a crucial step in fully understanding the risk posed by high nitrite levels to the aquatic animals.

Author Contributions: Conceptualization, G.N., C.A. and P.V.; Data curation, G.N., C.A. and P.V.; Formal analysis, G.F.; Investigation, G.N., G.F., C.A. and P.V.; Methodology, G.F.; Project administration, C.A.; Resources, C.A.; Software, G.F.; Validation, G.N., C.A. and P.V.; Writing-original draft, G.N., C.A. and P.V.; Writing-review and editing, G.N., C.A. and P.V. All authors have read and agreed to the published version of the manuscript.

Funding: This research did not receive any specific grant from funding agencies in the public, commercial, or not-for-profit sectors.

Institutional Review Board Statement: The study was conducted according to the guidelines of the Declaration of Helsinki, and approved by the Institutional Review Board (or Ethics Committee) of University of Naples Federico II, Naples, Italy (Approval number 47339-2013).

Data Availability Statement: The data presented in this study are available on request from the corresponding author.

Conflicts of Interest: The authors declare no conflict of interest.

\section{References}

1. Kroupová, H.K.; Valentová, O.; Svobodová, Z.; Šauer, P.; Máchová, J. Toxic effects of nitrite on freshwater organisms: A review. Rev. Aquacult. 2018, 10, 525-542. [CrossRef]

2. Kroupova, H.; Machova, J.; Svobodova, Z. Nitrite influence on fish: A review. Vet. Med. 2005, 50, 461-471. [CrossRef]

3. Romano, N.; Zeng, C. Toxic Effects of Ammonia, Nitrite, and Nitrate to Decapod Crustaceans: A Review on Factors Influencing their Toxicity, Physiological Consequences, and Coping Mechanisms. Rev. Fish. Sci. Aquac. 2013, 21, 1-21. [CrossRef]

4. Jensen, F.B. Nitrite disrupts multiple physiological functions in aquatic animals. Comp. Biochem. Physiol. 2003, 135, 9-24. [CrossRef]

5. Kozák, P.; Máchová, J.; Policar, T. The effect of chloride content in water on the toxicity of sodium nitrite for spiny-cheek crayfish. Bull. Fr. Pêche Piscic. 2005, 376, 705-714. [CrossRef]

6. Margiocco, C.; Arillo, A.; Mensi, P.; Schenone, G. Nitrite bioaccumulation in Salmo gairdneri Rich. and hematological consequences. Aquat. Toxicol. 1983, 3, 261-270. [CrossRef]

7. Cheng, S.Y.; Chen, J.C. Accumulation of Nitrite in the Tissues of Penaeus monodon Exposed to Elevated Ambient Nitrite after Different Time Periods. Arch. Environ. Contam. Toxicol. 2000, 39, 183-192. [CrossRef]

8. Shiva, S.; Huang, Z.; Grubina, R.; Sun, J.; Ringwood, L.A.; MacArthur, P.H.; Xu, X.; Murphy, E.; Darley-Usmar, V.M.; Gladwin, M.T. Deoxymyoglobin is a nitrite reductase that generates nitric oxide and regulates mitochondrial respiration. Circ. Res. 2007, 100, 654-661. [CrossRef] [PubMed]

9. Hannas, B.R.; Das, P.C.; Li, H.; LeBlanc, G.A. Intracellular conversion of environmental nitrate and nitrite to nitric oxide with resulting developmental toxicity to the crustacean Daphnia magna. PLoS ONE 2010, 5, e12453. [CrossRef] [PubMed]

10. Tipsmark, C.K.; Madsen, S.S. Regulation of $\mathrm{Na}^{+} / \mathrm{K}^{+}$-ATPase activity by nitric oxide in the kidney and gill of the brown trout (Salmo trutta). J. Exp. Biol. 2003, 206, 1503-1510. [CrossRef]

11. Clementi, E.; Brown, G.C.; Foxwell, N.; Moncada, S. On the mechanism by which vascular endothelial cells regulate their oxygen consumption. Proc. Natl. Acad. Sci. USA 1999, 96, 1559-1562. [CrossRef] [PubMed] 
12. Filippovich, S.Y.; Onufriev, M.V.; Peregud, D.I.; Bachurina, G.P.; Kritsky, M.S. Nitric-Oxide Synthase Activity in the Photomorphogenesis of Neurospora crassa. Appl. Biochem. Microbiol. 2020, 56, 446-452. [CrossRef]

13. Caldwell, R.B.; Toque, H.A.; Narayanan, S.P.; Caldwell, R.W. Arginase: An old enzyme with new tricks. Trends Pharmacol. Sci. 2015, 36, 395-405. [CrossRef] [PubMed]

14. Morris, S.M., Jr. Recent advances in arginine metabolism: Roles and regulation of the arginases. Br. J. Pharmacol. 2009, 157, 922-930. [CrossRef] [PubMed]

15. Wu, C.; Morris, S. Arginine metabolism: Nitric oxide and beyond. Biochem. J. 1998, 336, 1-17. [CrossRef]

16. Romero, M.J.; Platt, D.H.; Tawfik, H.E.; Labazi, M.; El-Remessy, A.B.; Bartoli, M.; Caldwell, R.B.; Caldwell, R.W. Diabetes-induced coronary vascular dysfunction involves increased arginase activity. Circ. Res. 2008, 102, 95-102. [CrossRef] [PubMed]

17. Katusic, Z.S.; d'Uscio, L.V.; Nath, K.A. Vascular protection by tetrahydrobiopterin: Progress and therapeutic prospects. Trends Pharmacol. Sci. 2009, 30, 48-54. [CrossRef] [PubMed]

18. Jensen, F.B. Nitric oxide formation from nitrite in zebrafish. J. Exp. Biol. 2007, 210, 3387-3394. [CrossRef] [PubMed]

19. Barley, A.J.; Coleman, R.M. Habitat structure directly affects aggression in convict cichlids Archocentrus nigrofasciatus. Curr. Zool. 2010, 56, 52-56. [CrossRef]

20. Rodela, T.M.; Wright, P.A. Characterization of diurnal urea excretion in the mangrove killifish, Rivulus marmoratus. J. Exp. Biol. 2006, 209, 2696-2703. [CrossRef] [PubMed]

21. Chen, J.C.; Chen, S.F. Accumulation of nitrite in the haemolymph of Penaeus monodon exposed to ambient nitrite. Arch. Environ. Contam. Toxicol. 1992, 103, 477-481. [CrossRef]

22. Dalla Via, J.; van den Thillart, G.; Cattani, O.; de Zwaan, A. Influence of long-term hypoxia exposure on the energy metabolism of Solea solea. II. Intermediary metabolism in blood, liver and muscle. Mar. Ecol. Prog. Ser. 1994, 111, 17-27. [CrossRef]

23. Shechter, H.; Gruener, N.; Shuval, H.I. A micromethod for the determination of nitrite in blood. Anal. Chim. Acta 1972, 60, 93-99. [CrossRef]

24. Huertas, M.; Gisbert, E.; Rodrıguez, A.; Cardona, L.; Williot, P.; Castello-Orvay, F. Acute exposure of Siberian sturgeon (Acipenser baeri, Brandt) yearlings to nitrite: Median-lethal concentration (LC50) determination, haematological changes and nitrite accumulation in selected tissues. Aquat. Toxicol. 2002, 57, 257-266. [CrossRef]

25. Dunn, J.F.; Hochachk, P.W. Metabolic responses of trout (Salmo gairdneri) to acute environmental hypoxia. J. Exp. Biol. 1986, 123, 229-242. [CrossRef]

26. Gornall, A.G.; Bardawill, C.J.; David, M.M. Determination of serum proteins by means of the biuret reaction. J. Biol. Chem. 1949, 177, 751-766. [CrossRef]

27. Wright, P.A.; Felskie, A.; Anderson, P.M. Induction of ornithine- urea cycle enzymes and nitrogen metabolism and excretion in rainbow trout (Oncorhynchus mykiss) during early life stages. J. Exp. Biol. 1995, 198, 127-135. [CrossRef] [PubMed]

28. Iwata, K.; Kajimura, M.; Sakamoto, T. Functional ureogenesis in the gobiid fish Mugilogobius abei. J. Exp. Biol. 2000, 203, 3703-3715. [CrossRef] [PubMed]

29. Rahmatullah, M.; Boyde, T.R. Improvements in the determination of urea using diacetyl monoxime; methods with and without deproteinisation. Clin. Chim. Acta 1980, 107, 3-9. [CrossRef]

30. Jeberg, M.V.; Jensen, F.B. Extracellular and intracellular ionic changes in crayfish Astacus astacus exposed to nitrite at two acclimation temperatures. Aquat. Toxicol. 1994, 29, 65-72. [CrossRef]

31. Stormer, J.; Jensen, F.B.; Rankin, J.C. Uptake of nitrite, nitrate, and bromide in rainbow trout, Oncorhynchus mykiss: Effects on ionic balance. Can. J. Fish. Aquat. Sci. 1996, 53, 1943-1950. [CrossRef]

32. Jensen, F.B. Physiological Effects of Nitrite in Teleosts and Crustaceans. In Toxicology of Aquatic Pollution: Physiological, Cellular and Molecular Approaches; Taylor, E.W., Ed.; Cambridge University Press: Cambridge, UK, 1996; pp. 169-186.

33. Regnault, M. Nitrogen excretion in marine and freshwater crustacea. Biol. Rev. 1987, 62, 1-24. [CrossRef]

34. Nelson, S.G.; Armstrong, D.A.; Knight, A.W.; Li, H.W. The effects of temperature and salinity on the metabolic rate of juvenile Macrobrachium rosenbergii (Crustacea: Palaemonidae). Comp. Biochem. Physiol. 1977, 56, 533-537. [CrossRef]

35. Lee, W.C.; Chen, J.C. Nitrogenous excretion and arginase specific activity of kuruma shrimp Marsupenaeus japonicus exposed to elevated ambient nitrite. J. Exp. Mar. Biol. Ecol. 2004, 308, 103-111. [CrossRef]

36. Choudhury, S.R.; Borkotoky, A.; Mahanta, R. Excretory pattern of ammonia and urea and the activity of glutamate dehydrogenase in freshwater fish, Labeo rohita. World J. Med. Sci. 2012, 2, 54.

37. McDonald, M.D.; Smith, C.P.; Walsh, P.J. The physiology and evolution of urea transport in fishes. J. Membr. Biol. 2006, 212, 93-107. [CrossRef] [PubMed]

38. De Boeck, G.; Alsop, D.; Wood, C. Cortisol Effects on Aerobic and Anaerobic Metabolism, Nitrogen Excretion, and Whole-Body Composition in Juvenile Rainbow Trout. Physiol. Biochem. Zool. 2001, 74, 858-868. [CrossRef]

39. Ip, A.Y.K.; Chew, S.F. Ammonia Production, Excretion, Toxicity, and Defense in Fish: A Review. Front. Physiol. 2010, 1. [CrossRef] [PubMed]

40. Yu, J.; Ji, X.; Wang, X.; Li, T.; Wang, H.; Zeng, Q. Identification and characterization of differentially expressed genes in hepatopancreas of oriental river prawn Macrobrachium nipponense under nitrite stress. Fish. Shellfish Immunol. 2019, 87, 144-154. [CrossRef]

41. Benzer, F.; Özçelik, M.; Yildirim, N.C. The Effects of Dietary Antioxidants on the Arginase Activity and NitricOxide Level of Narrow-Clawed Turkish Crayfish (Astacus leptodactylus Esch. 1823) in Moulting Period. Turk. J. Fish. Aquat. Sci. 2016, 16, $283-288$. 
42. Sands, J.M.; Timmer, R.T.; Gunn, R.B. Urea transporters in kidney and erythrocytes. Am. J. Physiol. 1997, 273, F321-F339. [CrossRef] [PubMed]

43. Rui, J.; Cen, H.; Ji-Lin, L.; Bao-Liang, L.; Bin, H.; Huan-Huan, H.; Shu-Ting, Y. Effects of nitrite exposure on haematological parameters, oxidative stress and apoptosis in juvenile turbot (Scophthalmus maximus). Aquat. Toxicol. 2015, 169, 1-9.

44. Cheng, C.H.; Su, Y.L.; Ma, H.L.; Deng, Y.Q.; Feng, J.; Chen, X.L.; Jie, Y.K.; Guo, Z.X. Effect of nitrite exposure on oxidative stress, DNA damage and apoptosis in mud crab (Scylla paramamosain). Chemosphere 2020, 239, 124668. [CrossRef] [PubMed]

45. Li, J.; Jia, W.; Zhao, Q. Excessive nitrite affects zebrafish valvulogenesis through yielding too much NO signaling. PLoS ONE 2014, 9, e92728.

46. Venditti, P.; Napolitano, G.; Di Meo, S. Role of Mitochondria and Other ROS Sources in Hyperthyroidism-Linked Oxidative Stress. Immunol. Endocr. Metab. Agents Med. Chem. (under Re-Organ.) 2015, 15, 5-36. [CrossRef]

47. Sikka, G.; Pandey, D.; Bhuniya, A.K.; Steppan, J.; Armstrong, D.; Santhanam, L.; Nyhan, D.; Berkowitz, D.E. Contribution of arginase activation to vascular dysfunction in cigarette smoking. Atherosclerosis 2013, 231, 91-94. [CrossRef] [PubMed]

48. Wang, W.N.; Wang, A.L.; Zhang, Y.J. Effect of dietary higher level of selenium and nitrite concentration on the cellular defense response of Penaeus vannamei. Aquaculture 2006, 256, 558-563. [CrossRef]

49. Sun, S.; Ge, X.; Zhu, J.; Xuan, F.; Jiang, X. Identification and mRNA expression of antioxidant enzyme genes associated with the oxidative stress response in the Wuchang bream (Megalobrama amblycephala Yih) in response to acute nitrite exposure. Comp. Biochem. Physiol. Part C 2014, 159, 69-77. [CrossRef]

50. Guo, H.; Lin, W.; Wu, X.; Wuang, L.; Zhang, D.; Li, L.; Li, D.; Tang, R.; Yang, L.; Qiu, Y. Survival strategies of Wuchang bream (Megalobrama amblycephala) juveniles for chronic ammonia exposure: Antioxidant defense and the synthesis of urea and glutamine. Comp. Biochem. Physiol. C Toxicol. Pharmacol. 2020, 230, 108-707. [CrossRef] [PubMed]

51. Lukash, A.I.; Kartashev, I.P.; Antipina, T.V. Uchastie ionov zheleza v antioksidantnom derstvii mocheviny [Participation of iron ions in antioxidant action of urea]. Ukr Biokhim. Zh (1978) 1980, 52, 462-465. 